\title{
Information Technology and the Ambidexterity Hypotheses: An Analysis in Product Development
}

\author{
Elena Revilla \\ IE Business School, Madrid, Spain \\ elena.revilla@ie.edu \\ Isabel $\mathrm{M}^{\mathrm{a}}$ Prieto \\ Universidad de Valladolid, Spain \\ isabo@eco.uva.es \\ Beatriz Rodríguez \\ Universidad de Valladolid, Spain \\ brodriguez@eco.uva.es
}

\begin{abstract}
This paper explores ambidexterity, defined as the capacity to simultaneously achieve exploration and exploitation activities at a product development level. Building on the knowledge-based view literature, it is argued that information technology -defined by a combination of convergent and divergent dimensions- may facilitate ambidexterity in the context of product development. Furthermore, ambidexterity mediates the relationship between information technology and performance. Data collected from 80 product development projects supports our hypotheses. Most importantly, the study presents evidence that ambidexterity mediates the relationship between the information technology that encourages exploration and exploitation and subsequent performance in product development.
\end{abstract}

Keywords: Product Development, Ambidexterity, Information Technology, Performance, Knowledge Management

\section{INTRODUCTION}

Knowledge is an intangible strategic resource able to create value and achieve superior performance (Grant, 1996; Hult, Ketchen, Cavusgil and Calantone, 2006; Mohrman, Finegold and Mohrman, 2003). In general, researchers recognize that product development is a knowledge-based activity (Clark and Fujimoto, 1991) that denotes knowledge management processes as the only way to ensure survival and success (Mallick and Schroeder, 2005). Product developments is thus a major focus of emphasis for organizations (Handfield and Nichols, 2002; Fliess and Becker, 2006). Developing highly successful products demands firms to employ their existing knowledge while at the same time avoiding their dysfunctional rigidity effects by renewing and replacing this knowledge with new knowledge (Atuahene-Gima, 2005; Atuahene and Murray, 2007; Knott, 2002; Sheremata, 2000). Therefore product development involves both exploring knowledge and exploiting knowledge, yet tensions emanate from their different knowledge management processes (March, 1991; Tushman and O'Reilly, 1996). The management of these tensions concerns the capability to be ambidextrous, which implies simultaneous, yet contradictory, knowledge management processes, exploiting current competences while exploring new ones with equal dexterity (Andriopoulus and Lewis, 2009; Jansen, Van den Bosch and Volverda, 2005). Successful firms are those able to balance both exploration and exploitation by being ambidextrous and in so doing enhance their long-term competitiveness (Auh and Menguc, 2005; Gibson and Birkinshaw, 2004; He and Wong, 2004; Tushman and O’Reilly, 1996).

Latest research focuses on how firms can achieve ambidexterity. This increasing attention has contributed to the refinement and extension of the ambidexterity concept (Raisch, Birkinshaw, Probst and Tusman, 2009) and to suggest multiple paths to 
ambidexterity. Originally, Duncan (1976), and later Tushman and O'Reilly (1996), analyze architectural ambidexterity by recognizing the role of dual structures within organizations, differentiating efforts to focus on either exploration or exploitation. In contrast, Gibson and Birkinshaw (2004) introduce the alternative view of contextual ambidexterity to analyze the social and behavioral means to integrate exploration and exploitation. The structural and contextual antecedents have been extended to investigations of the roles played by networks (Kauppila, 2007), and leadership-based antecedents of ambidexterity (Lubatkin, Simsek, Ling and Veiga, 2006; Smith and Tushman, 2005). This body of work has been categorized and discussed in recent review papers (Raisch and Birkinshaw, 2008; Raisch et al., 2009) that indicate that although both exploration and exploitation are necessary, their contradictions motivate important research issues that remain unexplored, ambiguous, or conceptually vague. For that reason, attempts to achieve ambidexterity continue to be a challenge and the need to address how firms can be ambidextrous still remains.

This paper focuses on ambidexterity in product development -which has been proved to be well suited to studying innovation tensions-, analyzing both the path and consequences for product development performance. Considering that March expressly suggests that his theory about exploration and exploitation might be applicable to the study of IT (March. 1991; March 1995), this study offer an alternative path to ambidexterity by analyzing the link between information technology (IT) - which is an established knowledge management enabler- and the exploration-exploitation paradox in product development. IT plays a critical role in product development since its potential range from the storing, organizing, processing and access of knowledge to the facilitation of people networks, coordinated flowing and integration of knowledge (Van den Brink, 2003). Previous literature notes that IT can thus influence both exploration and exploitation (Alavi and Leidner, 2001; Gray, 2001; Pentland, 1995; Sambamurthy and Subramani, 2005) and thus can affect the desired balance between them. Whereas existing research has provided contributions on the combined use of several IT mechanisms to support knowledge base capabilities (Sambamurthy and Subramani, 2005; Kane and Alavi, 2007), the mixed messages reflect the complexity of the problem and underscore the need for in-deep research. On the basis of these limitations, this study analyze the ex- ploration-exploitation paradox in product development by considering the integration of two kinds of IT dimensions: (1) the divergent dimension, which is focused on gathering and synthesizing information and knowledge, making it available for creative action; and (2) the convergent dimension, which is focused on knowledge discovering and analysis, and the support of discourse and virtual networking for enhancing collective action.

Specifically, this study proposes both the divergent and the convergent dimensions of IT as paths to ambidexterity and, additionally, analyzes how ambidexterity mediates the relationship between IT and product development performance. In doing so, this manuscript differs from previous research in a number of important ways. First, the contribution to ambidexterity literature comes by considering the use of IT as complementary pathway to achieve the desired balance between exploration and exploitation. Second, following Melville, Kraemer and Gurbaxani's (2004) suggestion on the importance of disaggregating IT construct into meaningful subcomponents, IT is not applied generically to ambidexterity, rather this study support the combined use of several IT mechanisms. Third, while the majority of past studies focus on the benefits of IT use for organizations, this study focuses on benefits for product development. Fourth, previous research highlights the need to examine financial performance, market share or a narrow range of operational performance measures as a primary performance outcome, but this study offers a model where the impact of IT on product development performance is mediated by ambidexterity.

The body of the paper first describes the nature of ambidexterity in product development and establishes the role of IT as an antecedent of ambidexterity. Next, it hypothesizes the relation of ambidexterity to product development performance, along with the mediation role of ambidexterity between IT and performance. The paper next includes the empirical analysis that test and support hypotheses, to conclude with a discussion of the empirical findings.

\section{AMBIDEXTERITY IN PRODUCT DEVELOP- MENT}

Research on product development from a knowledge-based view (Fedor, Ghos, Caldwell, Maurer and Singhal, 2003; Madhavan and Grover, 1998) recognizes that product development needs a fit 
between the exploitation of existing product competences and the exploration of new ones. March (1991) argues that exploration and exploitation are two facets of organizational learning that are inseparable. In the context of product development, exploitation involves an experience effect through the application of well defined market solutions closely related to the firm's previous experience. The emphasis on reusing knowledge leads to a deeper understanding of concepts, booting the firm's ability to identify its valuable knowledge, develop connections, and combine knowledge in different ways (Katila and Ahuja, 2002). At the same time, exploration in product development involves the search for market information that is new to the organization and exposes the firm to new domains and knowledge far from its current experience. This increases the diversity of current knowledge bases and competences by introducing variations through the alternative choices for problem solving (March, 1991) and increases the chance for innovation.

Accordingly, product development suits the concept of ambidexterity, conceptualized as the ability to simultaneously and internally address exploration and exploitation. The origins of ambidexterity may be traced to the work of Duncan (1976), but in the recent years the concept has gained momentum in research on organizations (Raisch et al., 2009). Table 1 shows several approaches to the concept of ambidexterity and details its conflicting demands. These demands differ in their emphases and, although near consensus exist on the need of ambidexterity, considerably less clarity exists on how to achieve it (Jansen et al. 2005).

\section{Table 1. Conceptualizations of ambidexterity}

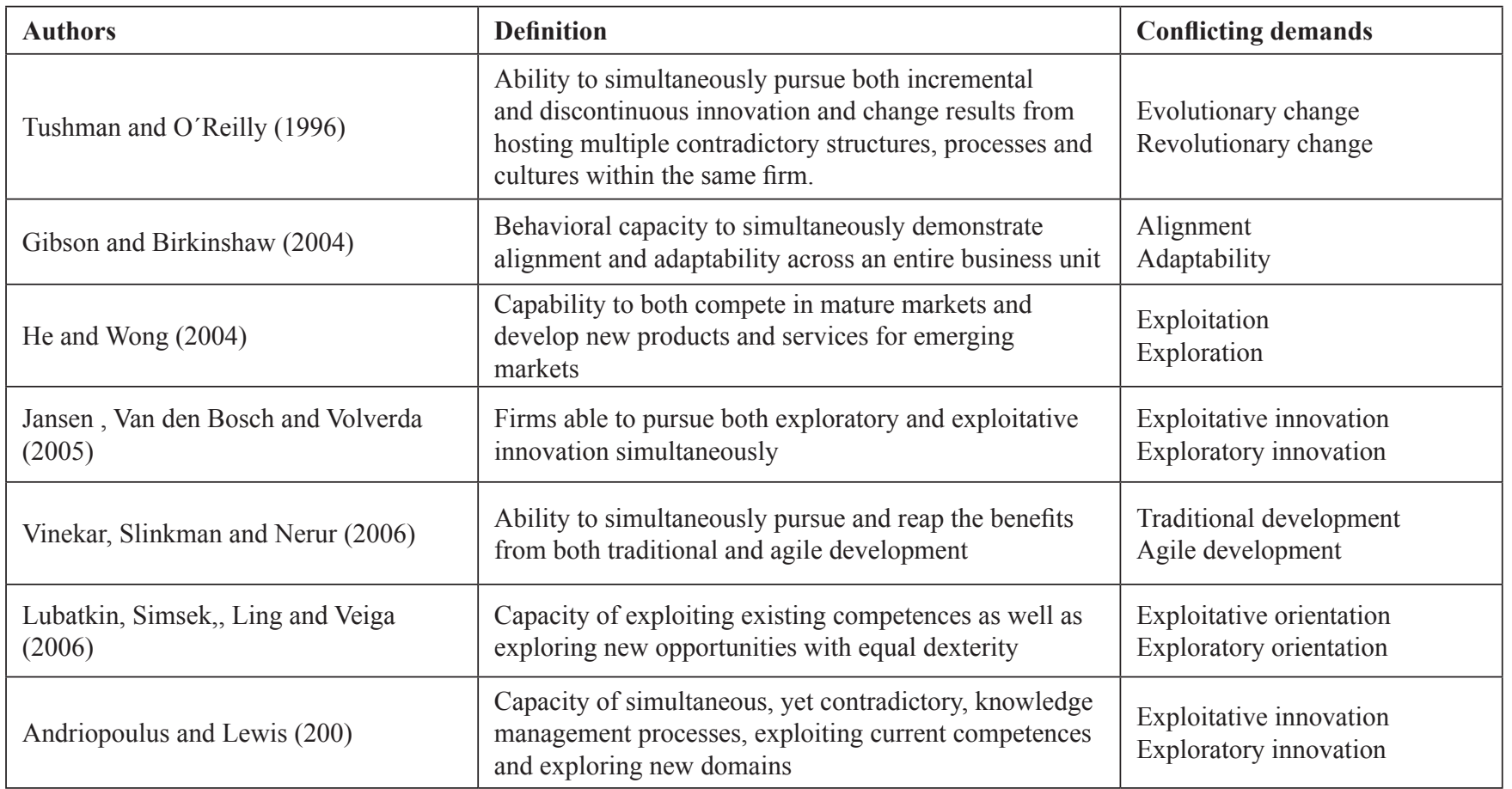

Ambidexterity is often described as one of the toughest challenges that managers have to face because exploration and exploitation entail contradictory processes regarding the use of knowledge, distinct managerial practices, and different tactics (Andriopoulus and Lewis, 2009; Benner and Tushman, 2003; Floyd and Lane, 2000; Katila and Ahuja, 2002; Raisch et al., 2009). The literature has thus focused on different approaches that enable ambidexterity. One of the most significant approaches, prompted by Tushman and O' Reilly (1996), describes ambidexterity in architectural terms, suggesting that ambidextrous organizations encompass dual structures and strategies, some focused on exploration and some focused on exploitation. Differentiated efforts target either exploration or exploitation. Related tactics rely on spatial and/or temporal separation. On the contrary, a different approach, leaded by authors such as Gib- 
son and Birkinshaw (2004), describes contextual ambidexterity in terms of social and behavioral aspects as means to integrate exploration and exploitation. Behavioral integration requires a unity of effort through which individual employees, and especially top management, simultaneously demonstrate alignment and adaptability during their day-to-day work. Although most research examines specific tactics within one or the other approach (Andriopoulus and Lewis, 2009), some recent research efforts analyze the importance of both structural and contextual approaches to ambidexterity by proposing more comprehensive models of managing the tensions between exploration and exploitation. In example, Sheremata (2000) describes innovation as a tug-ofwar between centripetal and centrifugal forces that fuel discovery and synthesis, respectively. Jansen et al. (2005) similarly posit that organizational antecedents of exploratory and exploitative innovation include both formal (i.e. centralization and formalization) and informal (i.e. connectedness) coordination mechanisms. Andriopoulus and Lewis (2009) stress that both integration and differentiation tactics are central in the management of exploration- exploitation paradoxes.

The knowledge management literature has often accounted for the importance of structural means and contextual means to enable knowledge management processes underlying exploration and exploitation (Gold, Malhotra and Segards, 2001). Together with them, the knowledge management literature traditionally vindicates information technology (IT) as a crucial element for knowledge management activities (Alavi and Leidner, 2001; Nonaka and Takeuchi, 1995). Accordingly, this research suggests that IT complements the structural and contextual approaches to ambidexterity by offering divergent and convergence mechanism that act as pathways to ambidexterity. The study hypothesizes that the combination of complementary IT dimensions may shape the way product development achieve ambidexterity by simultaneously pursuing exploration and exploitation. The study also hypothesizes on the impact of ambidexterity on product development performance. These relations are depicted in Figure 1.

Figure 1. Relationships predicted

\begin{tabular}{|c|c|c|}
\hline IT & Ambidexterity & $\begin{array}{c}\text { Performance } \\
\text { Teamwork }\end{array}$ \\
\hline $\begin{array}{l}\text { Convergent IT } \\
\text { Divergent IT }\end{array}$ & $\begin{array}{l}\text { Exploration } \\
\text { Exploitation }\end{array}$ & Market performance \\
\hline
\end{tabular}

\section{Information technologies and ambidexterity}

Research claims that massive IT is often designed with overemphasis in the pole of exploiting knowledge, while neglecting the pole of exploration (Argyris, 1977; Stein and Zwass, 1995; Suchman, 1994). In this regard, IT causes, more than heals, some of the problems of organizations. Furthermore, some researchers have recently proposed a new model of IT that appears to be promising for ambidexterity. In example, Malhotra (2002) proposes what he calls loose tight IT systems as enablers of both poles of knowledge -exploration and exploitation- simultaneously. Other authors (Alavi and Leidner, 2001; Davenport and Prusak, 1998; Gold et al., 2001; Scott, 2000) also points out that IT is the anchor to achieve both exploration and exploitation, and thus ambidexterity (Sher and Lee, 2004).
Theories of information systems hold that IT within organizations serves, on one hand, to "automate" organizational tasks such as transaction, storing and processing of data and information. IT is thus accepted as a real pipeline to codify, organize and synthesize information and explicit documented knowledge, increasing the quantity and the quality of the knowledge, information and ideas that an organization can access at low expense. On the other hand, IT serves to "informate", and thus to support organizational decision making and the exchange of ideas (Sanders, 2008). In fact, IT can create an interconnected context as a medium to vertically and horizontally integrate efforts, knowledge and ideas into collective action, irrespectively of time and geographic dispersion (Sambamurthy and Subramani, 2005). According to these arguments, authors such as Sanders (2008), Kane and Alavi (2007) and Van 
den Brink (2003) suggest that an effective IT infrastructure demands a combination of complementary systems to properly manage both tacit and explicit knowledge. On the basis of it, this research differ- entiates two related IT dimensions, the convergent dimension and the divergent dimension, as enablers of ambidexterity. Both dimensions are described in Table 2.

Table 2. Description of IT dimensions

\begin{tabular}{|c|c|c|}
\hline IT Dimensions & Role and Importance & Tools \\
\hline Divergent IT & $\begin{array}{l}\text { - Connect people to explicit knowledge } \\
\text { - Have information and explicit knowledge } \\
\text { components online } \\
\text { - Easy access and retrieval of knowledge } \\
\text { - Point people to documents that describe or store } \\
\text { knowledge } \\
\text { - Create knowledge repositories }\end{array}$ & $\begin{array}{l}\text { - Office applications } \\
\text { - Integrated document management } \\
\text { - Decision support systems } \\
\text { - Data warehouse } \\
\text { - Internet, intranet } \\
\text { - Electronic libraries } \\
\text { - Yellow pages }\end{array}$ \\
\hline
\end{tabular}

The convergent dimension plays the role of connecting people to people, enhancing analysis and discourse, and supporting a virtual network that is not constrained by barriers of time and place. This dimension improves coordination and communication between members of product development by facilitating tacit knowledge transference from those who posses it to those who need or can use it. Tacit knowledge is thus managed and pooled into coordinated action. The aim is to facilitate collective action and teamwork regardless of time and geographic location, offering product development members the opportunity to interact and exchange views and thoughts with each other. Convergent IT can also increase the likelihood of discovery by finding solutions to problems and increasing the quality of those solutions and decisions. The divergent dimension concerns the quality and quantity of information and explicit knowledge that an organization can access, facilitating their indexing, mapping, and retrieval to all members of product development. This dimension plays the role of connecting people to explicit knowledge through knowledge components that have a structured content such as manuals, reports, articles, best practices, customer inquiries and needs, competitor analysis and experience with production. IT thus provides a content classification scheme to access and synthesize knowledge and to facilitate grouping, sorting visualization, searching, publication, manipulation, refinement and navigation. This way, explicit knowledge can be expressed in symbols, communicated, and used.

The combination of both the convergent dimension and the divergent dimension in product development configure the potential to support the exploration and the exploitation of knowledge. Following Zollo and Winter (2002), exploration activities are primarily carried out through cognitive efforts aimed at generating a necessary range of innovative intuitions and ideas as well as selecting the most appropriate ones through legitimating processes. By contrast, exploitation activities rely on behavioral mechanisms encompassing the retention and replication of knowledge. That being so, convergent IT may be assumed to be especially supportive of exploration activities by facilitating communication, discourse and discovery among members of product development effort, so that they can share their knowledge and ideas. So, this dimension of IT may increase knowledge exploration by enabling a knowledge space for constructing shared beliefs, for confirming consensual interpretation and for allowing expression of new ideas (Alavi and Leidner, 2001) so that experts come together to reach new insights and/or more accurate interpretations than 
they would on their own. Conversely, divergent IT is more supportive of exploitation activities by enhancing knowledge differentiation and application, and facilitating the capture, updating, and accessibility of existing knowledge (Alavi and Leidner, 2001). So, this IT dimension may be considered as a memory aid that helps in storing and reapplying workable solutions in the form of standards and procedures. Easily retrievable knowledge is used as input for intelligent agents, which replicate prior procedures to solve recurring problems. This dimension also increases the speed of retrieving and applying existing knowledge and ideas, both in a structured and unstructured form, to use it in creative action (Robey, Boudreau and Rose, 2000).

Accordingly, arguing that a path to ambidexterity in product development is the combination of the convergent and divergent dimensions of IT makes sense. Product development that engages in convergent IT and excludes divergent IT is likely to suffer the cost of experimentation without gaining many of the benefits. This is what Levinthal and March (1993) call the "failure trap". Likewise, product development that engages in divergent IT to the exclusion of exploration is likely to find itself trapped in suboptimal equilibrium. This is what Levinthal and March (1993) call the "success trap".

When product development has a proper alignment between convergent and divergent IT, it exhibits the higher level of ambidexterity. The divergent dimension of IT supports retrieving and synthesizing knowledge, ideas and information, which can then be applied to problem solving and creative action. The convergent dimension of IT integrates knowledge and ideas, pulling individuals to collaborate and discover solutions to known and unknown problems and decisions. Each dimension appears to affect different phases in problem solving, both dimensions interact and reinforce each other. Accordingly, the relationship between these dimensions may produce variations in ambidexterity.

$\mathrm{H}_{1}$ : When IT comprises a combination of convergent and divergent technologies, the levels of ambidexterity in product development will be higher.

\footnotetext{
${ }^{3}$ Municipal districts association of the Campos Gerais
}

\section{Ambidexterity and performance}

The ambidexterity premise suggests that the ability to achieve a balance between exploration and exploitation lead to superior performance outcomes. In general, this notion of balance has been conceptualized as implying that organizations that have high exploitation and high exploitation have higher performance (Atuahene-Gima and Murray, 2007). This interpretation is accorded to March's (1991) view, which maintains that an appropriate balance between explorative and exploitative learning is a crucial factor in a firm's effectiveness in product development.

Gaining better performance outcomes through product development involve a capability to physically make a new product and a capability to sell the product in the market. Performance in product development can thus adopt a process perspective, concerning the effectiveness of the product development process and the degree of collaborative teamwork (Zirger and Maidique, 1990) and a product perspective, concerning the characteristics associated to the product success in the market place (Clark and Wheelright, 1995). In view of this, this study analyzes the relationship ambidexterity-performance by considering product development performance as measurable by two outcomes: (1) process outcomes (e.g. teamwork); and (2) product outcomes (e.g. customer satisfaction). Particularly, the study argues that although exploration and exploitation strive for different objectives and have little in common with regard to their day-to-day operation, a central focus should permeate each of them: the need to improve efficiency within the product development team and its potential to create improved customer satisfaction. In other words, product development that achieves a balance between exploration and exploitation may have superior product development performance, both in terms of process and product. Exploitation activities are probably more closely geared to improving efficiency during the product development process, while exploration activities are probably more closely geared towards improving products' success in the market place.

Since knowledge is cumulative in nature, knowledge exploitation in product development reduces the likelihood of errors and provides deeper knowledge in particular areas (Levinthal and March, 1993) that lead the development of routines and ensures efficiency and implementation (Atuahene and Murray, 2007; Eisenhardt and Tabrizi, 1995; March, 1991). 
As a result, cooperation within the product development team is improved and complementary competences get properly coordinated and consolidated (Atuahene and Murray, 2007; Bierley and Daly, 2007). This also means that exploitation can lead to satisfy expressed customers needs and provide products with great value with a proper cost management (Menguc and Auh, 2008), although there is a risk of getting better and better at things that customers no longer value. In contrast, knowledge exploration requires high levels of creativity to go beyond the existing "zone of comfort", which directly affects the ability to add variants to the knowledge repertoire and to obtain innovative results. Exploration allows thus seizing new market opportunities and increases the potential to generating new products that fit customers' demands and differentiate from competitor's offerings (Atuahene and Murray, 2007; Katila and Ahuja, 2002). The risk of too much emphasis on exploration is, together with its cost, pursuing too many directions at once without a definite focus (Bierley and Daly, 2007), which could reduce the efficiency of the teamwork. In any case, the complementary effect between exploration and exploitation in product development may help to overcome the limitations of each of them and turn up their benefits.

$\mathrm{H}_{2}$ : Ambidexterity in product development relates positively to performance measured in terms of product and process outcomes.

\section{Mediation effects}

Finally, this study argues that ambidexterity mediates the relationship between convergent and divergent dimensions of IT and product development performance. That is, the attributes of IT dimensions influence product development performance through the achievement of ambidexterity. When ambidexterity dos not occur in product development, IT may have no influence on performance.

Previous research has shown that IT may indeed contribute to improve organizational performance, offering an extensive menu of potential benefits ranging from flexibility and quality improvement to cost reduction and productivity enhancement (Melville et al., 2004). For example, Tippins and Sohi (2003) argue that the ability to obtain, administer, and use information and knowledge about technology, markets and customers helps product development to be aware of environmental changes, and thus to achieve competitive advantages. However, even when IT has become a competitive necessity for most of the product development initiatives, no perfect understanding of how IT competences impact on performance exists. Studies examining the association between IT and performance differ in how they conceptualize key constructs and relationships (Melville, et al. 2004).

Information system researchers have begun to employ the resources perspective to expand and deepen the understanding of IT business value (Santhanam and Hartono, 2003). IT by itself is considered ineffective at providing a basis for sustainable competitive advantage because these competences could be easily replicated by competitors. Additionally, IT is considered valuable, but the extent and dimensions of its value are dependent upon other complementary organizational characteristics. In example, Tanriverdi (2005) suggests that knowledge management is a critical organizational capability through which IT influences performance. Bharadwaj (2000) analyses the association between superior IT capabilities and superior performance by defining IT capabilities as the synergistic combination of IT resources co-present with other organizational resources and capabilities. In a synthesis of studies examining the deployment of IT resources within organizations to improve performance, Melville et al. (2005) develop a conceptual framework which posits that IT impact organizational performance via intermediate business processes. Such research provides the foundation from which derive the integrative model proposed in this study.

Therefore, suggesting that a firm could simply institute (or imitate) the two dimensions of IT and expect them to deliver superior performance is erroneous. Rather, the impact of IT on performance in product development initiatives must be quantified by examining the indirect effect of some interesting product development process. In support of this argument, previous literature noted that IT can influence both exploration and exploitation, and thus ambidexterity. Accordingly, this study suggests that IT affect product development performance through their effects on ambidexterity.

$\mathrm{H}_{3}$ : Ambidexterity in product development mediates the relationship between IT -as a combination of convergent and divergent technologies- and product development performance. 


\section{RESEARCH METHODOLOGY}

\section{Sample characteristics and data collection}

The empirical analysis uses survey methodology. A questionnaire, designed and developed by authors from a thorough literature review, has been validated through a pre-test carried out through several personal interviews with product development executives. These interviews allow purifying survey items, and rectifying any potential deficiency. Minor adjustments are made on the basis of specific suggestions.

After the pilot study, the mailing list was obtained from Madri+d (Madrid, Spain). Madri+d (www.madridmasd.org) is a society that groups firms and public research organizations with the aim of improving competitiveness by encouraging $\mathrm{I}+\mathrm{D}$, innovation, and knowledge transfer. Madrid is one of the most developed areas in Spain (GDP per capita regularly above the national media, and the highest in 2006) and the one that concentrates the largest number of firms. By tapping into this area, the study gains a good insight into the effectiveness of various practices and is able to develop more credible constructs (Koufkeros, et al., 2007). Therefore, the population is composed of Spanish firms focused on R\&D and innovation operating in the local area of Madrid.

Madri+d integrates a list of 3293 organizations (including both public and private organizations) im- plicated in research and development activities, but not all them involved in new product development. For that reason, we have removed Public Research Centers (University and Public Research Organization) and service companies (such as consultancy, IT services and the like) from the list. The study then focuses on sectors where the incidence of product development is strong, providing a final list of 616 companies. Targeted respondents are product development managers that agreed to participate in the study. They received the questionnaire via e-mail or by accessing a web page where they could find it. They had to answer questions concerning a specific product development effort managed by them and finished in 2004. A researcher involved in the study personally helps respondents to solve any questions on the survey.

The data collection process yields 80 usable responses, for a response rate of $12.93 \%$. Table 3 shows the profile of participating companies and responses. In terms of industry type, answers cover a wide number of industries, mostly the food and beverage (20\%), chemistry and pharmaceutical $(11,3 \%)$, electric systems and electronics (10,1\%), computing systems $(7,5 \%)$, equipment manufacture $(5 \%)$ and transport (5\%). These percentages are similar to the ones in the original sample provided by Madrid $+\mathrm{d}$, so the final sample characteristics were not significantly different from the original one in terms of industry type proportion.

Table 3. Profile of participating companies

\begin{tabular}{|lc|}
\hline Number of employees & $\%$ \\
$<=499$ & 65.8 \\
$500-999$ & 9.6 \\
$1000-4999$ & 12.3 \\
$5000-9999$ & 6.8 \\
$>=10000$ & 5.5 \\
& \\
Age of the firm & \\
$1-10$ years & 24,4 \\
$11-50$ years & 60 \\
$>50$ years & 15,6 \\
& \\
Na tionality & \\
Spanish & \\
Multinational & 71,4 \\
\hline
\end{tabular}


Since a single response is asked from each product development, single informant bias in data collection might stem as a result. However, the presence of common method bias is tested by following the Harman's one-factor test described in Podsakoff, MacKenzie and Podsakoff (2003). According to this test, if common method variance were a serious problem in the study, it could be expected a single factor to emerge from a factor analysis or one general factor to account for most of the covariance in the independent and criterion variables (Aulakh and Gencturk, 2000). To apply the test, a factor analysis on all items is preformed. In this analysis, 12 factors emerge with eigenvalues greater than one (together explaining $75 \%$ of the variance) and the first factor accounts for only $22 \%$. Thus, the test suggests that common method variance is not of great concern. To assess size bias, the influence of firm size on the constructs was controlled by means of Anova tests. Results show that the null hypothesis of equal means could not been rejected and therefore firm size did not affect IT dimensions and knowledge capabilities (the F statistics for divergent and convergent dimensions were 0.368 and 0.789 , respectively and 0.45 and 0.527 for knowledge exploration and exploitation ).

\section{Measures description}

The measurement of the analysis variables is built on a multiple-items method, which enhances confidence about the accuracy and consistency of the assessment. Each item is based on a five point Likert scale and all of them are perceptual variables. Table 4 displays items used in the study.

\section{Product Development Ambidexterity}

Following Gibson and Birkinshaw (2004), this article conceptualizes ambidexterity as a multidimensional construct comprising the multiplicative interaction of exploration and exploitation. Based on Katila and Ahuja (2002), He and Wong (2004) and Lubatkin, Simsek, Ling and Veiga (2006), ambidexterity has been measured by using 8 items, four items concerning exploration and four items concerning exploitation. The first four items measure the degree to which product development introduces new ideas, new knowledge, and covers and corrects problem areas where customers were unsatisfied. The last four items measure the degree to which product development introduces lessons learnt in the past, existing competences and combines and integrates knowledge.

\section{Information Technology}

As previously argued, IT is measured by considering a convergent dimension and a divergent dimension. In the post hoc analysis, these dimensions are examined both independently and in combination. Based on Lee and Choi (2003) and Gold et al. (2001), IT is made operational by using nine items. Convergent dimension is assessed by considering the way IT fosters communication and collaboration into product development, inside and outside the organization (four items). Divergent dimension is measured by considering how much IT facilitates rapid collection, storage, mapping and formatting of knowledge, thereby assisting knowledge creation in product development (five items).

\section{Product Development Performance}

The dependent variable was measured through two components: Teamwork, which values process outcomes, and market performance, which values product outcomes. To capture process outcome, product development managers were thus asked about teamwork (i.e. quality of work, coordination, decisions efficiency, etc.). Items are taken from Hong, Vonderembse, Doll and Nahm (2005), who drawn them from Ali, Krapfel and LaBahn (1995), Crawford (1992), and Tersine and Hummingbird, (1995). To capture product outcomes, respondents are asked to consider market performance and to indicate the degree of satisfaction (Hong, 2000).

\section{ANALYSIS AND RESULTS}

Data analysis involves several steps. First, since research variables are measured through multipleitem constructs, the verification of items tapping into their stipulated construct is a requirement. Therefore, three independent factorial analyses are applied by using SPSS 13.0 for Windows: one for ambidexterity -exploration and exploitation- items, one for IT items, and the last one for process performance items. Table 4 summarizes results, together with internal consistency measures (Cronbach's alpha). Next, a new variable emerges from the multiplicative interaction between exploration and exploitation in order to measure ambidexterity. In the same way, an interaction variable using the multiplicative interaction of the convergent and divergent dimensions of IT reflects they should be considered holistically and complementary. 
Table 4. Definition of constructors and internal consistency measures

\begin{tabular}{|c|c|c|c|c|c|c|c|}
\hline & & & & & & Factoria & I analysis \\
\hline & Construct & Measurement item & Mean & S.D. & $\begin{array}{l}\text { Loading } \\
\text { Factor* }\end{array}$ & $\begin{array}{l}\text { Varian. } \\
\text { extract. } \\
(\%)\end{array}$ & $\begin{array}{l}\text { Cronbach's } \\
\text { alpha }\end{array}$ \\
\hline & & IT supports a systematic storing of information & 4.04 & 0.94 & 0.85 & & \\
\hline & & $\begin{array}{l}\text { IT supports mapping the location of knowledge and } \\
\text { information }\end{array}$ & 3.90 & 0.89 & 0.81 & & \\
\hline & $\begin{array}{l}\text { Divergent } \\
\text { dimension }\end{array}$ & $\begin{array}{l}\text { IT supports the search and access of a high level of } \\
\text { information about markets and competitors }\end{array}$ & 3.70 & 0.91 & 0.78 & 28.18 & 0.82 \\
\hline$\frac{0}{0}$ & & IT supports the clear formatting of knowledge & 3.63 & 0.88 & 0.71 & & \\
\hline 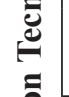 & & $\begin{array}{l}\text { IT supports the search and access of a high level of } \\
\text { information about products and processes }\end{array}$ & 4.01 & 0.65 & 0.64 & & \\
\hline : & & $\begin{array}{l}\text { IT supports collaborative work between people } \\
\text { outside the organization }\end{array}$ & 3.56 & 1.03 & 0.75 & & \\
\hline$\stackrel{\varrho}{\Xi}$ & Convergent & $\begin{array}{l}\text { IT supports collaborative works between the people } \\
\text { inside organization }\end{array}$ & 3.57 & 0.89 & 0.75 & & \\
\hline & dimension & $\begin{array}{l}\text { IT supports communication among members inside } \\
\text { the team of product development }\end{array}$ & 4.00 & 0.75 & 0.70 & 26.14 & 0.82 \\
\hline & & $\begin{array}{l}\text { IT supports communication with people outside the } \\
\text { organization }\end{array}$ & 3.94 & 0.82 & 0.66 & & \\
\hline & & $\begin{array}{l}\text { Product problem areas with which customer were } \\
\text { dissatisfied are corrected }\end{array}$ & 3.3 & 0.9 & 0.87 & & \\
\hline & & $\begin{array}{l}\text { Problem areas generating customer dissatisfaction } \\
\text { are covered }\end{array}$ & 3.2 & 1.0 & 0.85 & & \\
\hline & Exploration & $\begin{array}{l}\text { New knowledge, methods and inventions are } \\
\text { introduced }\end{array}$ & 3.6 & 0.8 & 0.75 & 33.55 & 0.83 \\
\hline E & & Many new novel and useful ideas are produced & 3.5 & 0.9 & 0.74 & & \\
\hline : & & $\begin{array}{l}\text { The team is able to identify valuable knowledge } \\
\text { elements, connect and combine them. }\end{array}$ & 3.9 & 0.8 & 0.80 & & \\
\hline & Fxnloitation & $\begin{array}{l}\text { The team makes use of existing competencies related } \\
\text { to products/services that are currently offered. }\end{array}$ & 3.9 & 0.8 & 0.76 & 2802 & 073 \\
\hline & Expioitation & $\begin{array}{l}\text { The team integrates new and existing ways of doing } \\
\text { things without stifling their efficiency. }\end{array}$ & 4.0 & 0.7 & 0.70 & 20.92 & 0.13 \\
\hline & & $\begin{array}{l}\text { Lessons learned in other areas of the organization } \\
\text { are put in operation }\end{array}$ & 3.9 & 0.9 & 0.67 & & \\
\hline & & $\begin{array}{l}\text { The team uses all product development resources } \\
\text { rationally }\end{array}$ & 3.6 & 0.7 & 0.79 & & \\
\hline & & The team implements decisions effectively & 4.0 & 0.7 & 0.84 & & \\
\hline 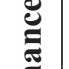 & & The team uses product engineering hours efficiently & 3.6 & 0.9 & 0.84 & & \\
\hline 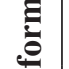 & Teamwork & The team coordinates activities well & 3.8 & 0.8 & 0.81 & 61.82 & 0.89 \\
\hline$\stackrel{\square}{\square}$ & & The team uses financial resources sensibly & 3.5 & 0.9 & 0.68 & & \\
\hline & & The team works well together & 4.1 & 0.7 & 0.75 & & \\
\hline & & The team is productive & 3.9 & 0.7 & 0.78 & & \\
\hline & $\begin{array}{c}\text { Market } \\
\text { performance }\end{array}$ & $\begin{array}{l}\text { Degree of market performance of product } \\
\text { development }\end{array}$ & 4.0 & 0.8 & & & \\
\hline
\end{tabular}

* Principal components 
In a second step, means, standard deviation and correlations among the variables are calculated (Table 5) (given that the study next works with the interaction variables, correlations among the IT dimensions and the ambidexterity components are not provided as they are not specifically informative). Ambidexterity is significantly and positively correlated with product development perfor- mance and, specially, teamwork. Ambidexterity is highly correlated with IT combination and this last variable is also significantly and positively related to product development performance. Essentially, correlations provide evidence that product development performance is related to both ambidexterity and IT combination. However, these relations deserve further analysis.

Table 5. Descriptive Statistics and Correlations

\begin{tabular}{|c|c|c|c|c|c|c|}
\hline & Mean & S.D. & Ambidexterity & Convergent*Divergent IT & Teamwork & Market Performance \\
\hline Ambidexterity & 8.73 & 4.49 & 1.00 & & & \\
\hline IT & 9.70 & 4.59 & $0.41 * *$ & 1.00 & & \\
\hline Teamwork & 2.68 & 1.00 & $0.41 * *$ & $0.23 *$ & 1.00 & \\
\hline Market Performance & 4.04 & 0.77 & $0.26 *$ & $0.20^{*}$ & 0.34 & 1.00 \\
\hline
\end{tabular}

${ }^{* *} \mathrm{p}<0.01,{ }^{*} \mathrm{p}<0.05$

Next, hypotheses are tested using ordinary least square (OLS) regression. Hypothesis $\mathrm{H}_{1}$ predicts that IT (the multiplicative interaction of dimensions of IT) is positively related to ambidexterity (that is, the multiplicative interaction of exploration and exploitation). As shown in Model 3 (see table 6), this prediction is supported (Beta=.41, $\mathrm{p}<0.001)$. Hypothesis $\mathrm{H}_{2}$ predicts a positive association between ambidexterity and product development performance. Consistent with this prediction, the beta coefficients for ambidexterity in Model 1 and Model 2 are positive and significant (Model 1, Beta=.41, p<.001), (Model 2, Beta=.26, $\mathrm{p}<.05$ ).

Table 6. Results of Regression Analysis

\begin{tabular}{lccccccc}
\hline Variable & $\begin{array}{c}\text { Model 1: } \\
\text { Dependent } \\
\text { Variable, } \\
\text { Teamwork }\end{array}$ & $\begin{array}{c}\text { Model 2: } \\
\text { Dependent } \\
\text { Variable, } \\
\text { Market } \\
\text { performance }\end{array}$ & $\begin{array}{c}\text { Model 3: } \\
\text { Dependent } \\
\text { Variable, } \\
\text { Ambidexterity }\end{array}$ & $\begin{array}{c}\text { Model 4: } \\
\text { Dependent } \\
\text { Variable, } \\
\text { Teamwork }\end{array}$ & $\begin{array}{c}\text { Model 5: } \\
\text { Dependent } \\
\text { Variable, } \\
\text { Market } \\
\text { performance }\end{array}$ & $\begin{array}{c}\text { Model 6: } \\
\text { Dependent } \\
\text { Variable, } \\
\text { Teamwork }\end{array}$ & $\begin{array}{c}\text { Model 7: } \\
\text { Dependent } \\
\text { Variable, } \\
\text { Market } \\
\text { performance }\end{array}$ \\
\hline $\begin{array}{l}\text { Ambidexterity } \\
\text { IT }\end{array}$ & $0.41^{* *}$ & $0.26^{*}$ & & & & $0.38^{* *}$ & $0.21+$ \\
& & & $0.41^{* *}$ & $0.23^{*}$ & $0.2+$ & 0.07 & 0.11 \\
$\mathrm{R}^{2}$ & 0.17 & 0.07 & 0.17 & 0.05 & 0.04 & 0.17 & 0.07 \\
Adjusted R ${ }^{2}$ & 0.15 & 0.05 & 0.16 & 0.04 & 0.03 & 0.15 & 0.05 \\
ANOVAF & $14.82^{* *}$ & $5.23^{*}$ & $15.6^{* *}$ & $4.09^{*}$ & $3.07+$ & $7.50^{* *}$ & $3.07^{*}$ \\
\hline
\end{tabular}

${ }^{* *} \mathrm{p}<0.01 ;{ }^{*} \mathrm{p}<0.05 ;+\mathrm{p}<0.1$ All regressions include a constant. Beta coefficient displayed

Hypothesis $\mathrm{H}_{3}$ predicts the mediating effect of ambidexterity in the relationship between IT -as captured by the convergent and divergent dimension- and product development performance. Procedures of Gibson and Birkinshaw (2004), building upon the ideas of Baron and Kenny (1986), Kenny et al. (1998), and Mackinnon and Dwyer (1993) are used to test hypothesis $\mathrm{H}_{3}$. Accordingly, the analysis of the medi- ation effect involves three steps. In the first step, the independent variable (here, IT) is regressed on the mediator (ambidexterity). In this step, IT emerged as significant predictor of ambidexterity (see Model 3, Table 6). In the second step, the independent variable (IT) is regressed on the dependent variable (product development performance in terms of teamwork and market performance). This step is supported in 
Model 4 and Model 5 in Table 6. IT had a significant positive relationship with performance in terms of both teamwork and market performance (Model 4, Beta=.23, $\mathrm{p}<.05$ ), (Model 5, Beta=.20, $\mathrm{p}<.1$ ). In the third step, the mediator (ambidexterity) is regressed on the dependent variable, with the independence variable (IT) controlled. If, in this final step, when ambidexterity is added to the equation, the effect of IT in performance is no longer significant, full mediation is indicated. As shown in Model 6 and Model 7 , with ambidexterity in the equation, the coefficient for IT is no longer significant, but ambidexterity has a positive and significant relationship with both teamwork and market performance. Both the size of the coefficient for IT and the corresponding test statistic for significant differences $(t)$ decreased from Model 4 and Model 5 (Model 4, Beta=.227, $\mathrm{t}=2.02$, $\mathrm{p}<.05)$, (Model 5, Beta=.20, $\mathrm{t}=1.75, \mathrm{p}<.1)$ to Model 6 and Model 7 (Model 6, Beta $=.07, \mathrm{t}=.56$, n.s.), (Model 7, Beta $=.12, \mathrm{t}=0.96$, n.s.).

To further test hypothesis $\mathrm{H}_{3^{\prime}}$ the use of a modification of the Sobel test proposed by Baron and Kenny (1986) provides a direct test of the indirect effect of an independent on the dependent variable through the mediator. According to Kenny, Kashy and Bolg- er (1998:260), the amount of mediation is defined as "the reduction of the effect on the initial variation on the outcome". To perform the test, the mediation effect is divided by its standard error, thus obtaining a Z-score (the z-statistic under the null hypothesis has approximately a Normal distribution; therefore values larger than 1.96 in absolute value permit to reject the null hypothesis at 0.05 significance level ). Results indicate that the mediation effect is statistically significant in both cases $(Z=3.84$ for teamwork; $\mathrm{Z}=2.28$ for market performance), supporting the full meditation proposed in Hypothesis $\mathrm{H}_{3}$.

\section{Post hoc analysis}

To gain additional insights, several post hoc analyses are conducted. The scatter graph of exploration and exploitation suggests the possibility of identifying some meaningful clusters, so some cluster analysis are undertaken to facilitate the specification of groups. Specifically, Ward's hierarchical method using the Euclidean distance as an agglomeration schedule leads to determine both the number of clusters and the initial seeds (centres of the groups) that are next introduced in a second K-means no hierarchical analysis that provides the final categorization of firms.

Table 7. Results of Cluster Analysis of Ambidexterity Activities (K-means)

\begin{tabular}{ccccc}
\hline & $\begin{array}{c}\text { Lowly ambidextrous } \\
\text { Product development }\end{array}$ & $\begin{array}{c}\text { Exploitation-based } \\
\text { product development }\end{array}$ & $\begin{array}{c}\text { Highly ambidextrous } \\
\text { Product development }\end{array}$ & TOTAL \\
\hline Exploration & $2.79(0.6)$ & $1.66(0.7)$ & $4.13(0.6)$ & $2.80(1.0)$ \\
\hline Exploitation & $2.52(0.7)$ & $3.88(0.8)$ & $3.84(0.7)$ & $3.02(1.0)$ \\
\hline $\mathbf{N}$ & 46 & 17 & 15 & 78 \\
\hline
\end{tabular}

In brackets standard deviation

The characterization of clusters, based on the final centres of K-means analysis, is displayed in Table 7. Cluster 1 , including 46 product development projects with low exploration and exploitation, represents a lowly ambidextrous product development. Cluster 2, comprising 17 product developments characterized by high exploitation but very low exploration, presents an exploitation-based product development. Clus- ter 3, formed by 15 product developments, shows a high exploration and exploitation, clearly representing a highly ambidextrous product development. Table 9 also shows the non-existence of product development with low emphasis on exploitation and high emphasis in exploration. This result illustrates the strong cumulative nature of scientific knowledge. 
Table 8. ANOVA Results for Effects of Exploration/Exploitation Configuration on Product Development Performance (Teamwork)

\begin{tabular}{|lc|}
\hline CLUSTERS & Teamwork \\
\hline Lowly ambidextrous product development & $2.62(0.92)$ \\
Exploitation-based product development & $2.98(1.16)$ \\
Highly ambidextrous product development & $3.37(0.85)$ \\
\hline Total & $2.84(1.00)$ \\
\hline F (Signif.) & $3.66^{*}$ \\
\hline
\end{tabular}

In brackets standard deviation. ${ }^{*} \mathrm{p}<0.05$.

Next, the relationship between exploration and exploitation and product development performance is analyzed through descriptive statistics (mean and deviation values) and ANOVA test for the segmented configurations (Table 8). The ANOVA F-test is highly significant and indicates that the null hypothesis (all three groups have the same performance level $[\mathrm{F}=3.66, \mathrm{p}<0.05])$ could be rejected. Product development of highly ambidextrous group (cluster 3 ) is the best performing (highest mean value), followed by exploitation-based (cluster 2) and lowly ambidex- trous (cluster 1). Additional support for the proposed framework emerges from the analysis, suggesting that the ability to be ambidextrous is an important predictor of product development performance.

A cluster analysis is also applied to the factors of the IT dimensions (Revilla, Rodriguez-Prado and Prieto, 2009). This cluster analysis leads to define different IT configurations in terms of the convergent and divergent dimensions. Again both IT measures have discriminatory power.

Table 9. Results of Cluster Analysis of Information Technology (K-means)

\begin{tabular}{ccccc}
\hline & $\begin{array}{c}\text { Balance IT } \\
\text { configuration }\end{array}$ & $\begin{array}{c}\text { Convergent-based IT } \\
\text { configuration }\end{array}$ & $\begin{array}{c}\text { Divergent-based IT } \\
\text { configuration }\end{array}$ & TOTAL \\
\hline Convergent & $3.61(0.63)$ & $3.62(0.42)$ & $1.90(0.61)$ & $\begin{array}{c}3.07 \\
(1.0)\end{array}$ \\
\hline Divergent & $3.57(0.68)$ & $1.36(0.64)$ & $3.09(0.77)$ & $\begin{array}{c}3.14 \\
(1.0)\end{array}$ \\
\hline $\mathbf{N}$ & 44 & 10 & 24 & 78 \\
\hline
\end{tabular}

In brackets standard deviation

Table 9 displays the characterization of the clusters. Cluster 1, including 44 product developments with high convergence and divergent IT dimensions, represents a balanced IT configuration. Cluster 2, comprising only 10 product developments characterized by high convergent IT dimension but very low divergent IT dimension, represents a convergent-based IT configuration. Cluster 3, formed by 24 product developments, differs from the other two groups because the convergent dimension is very low. Although the divergent IT dimension of this group showed more variability when compared to the other two clusters, a divergent-based IT configuration I considered to emerge here. Table 9 also shows the non-existence of product development with low emphasis on both convergent and divergent IT. The result thus points out the role of IT in enabling learning and knowledge sharing in product development.

The relationship between product development performance and IT configurations in product development is next analyzed within each cluster/configuration. Table 10 shows descriptive statistics (mean and deviation values) and ANOVA test. Again the ANOVA F-test is highly significant and indicated that the null hypothesis (all three groups have the same product development performance level $[\mathrm{F}=6,96, \mathrm{p}<0.01]$ ) could be rejected. Product development in the balanced IT configuration (cluster 1) are the best performing (highest mean value), followed by the divergent-based IT configuration (cluster 3) and the convergent-based IT configuration (cluster 2). The result also provides additional support. Balance IT configuration clearly im- 
proves on the convergent-based IT configuration and the divergent-based IT configuration, which suggests that the ability to have both IT dimensions is also an important predictor of performance.

\section{Table 10. ANOVA Results for Effects of Information Technology on Product Development Performance (Teamwork)}

\begin{tabular}{|lc|}
\hline CLUSTERS & Teamwork \\
\hline Balance IT configuration & $3.15(0.83)$ \\
Convergent-based IT configuration & $2.02(1.34)$ \\
Divergent-based IT configuration & $2.62(0.91)$ \\
\hline Total & $2.84(1.00)$ \\
\hline F (Signif.) & $6.96^{*}$ \\
\hline
\end{tabular}

In brackets standard deviation

${ }^{*} \mathrm{p}<0.05 ;+\mathrm{p}<0.1$

\section{DISCUSSION}

This study contributes to research on product development success -a central issue to researchers and managers alike. The research question guiding this study is: How does the confluence of knowledge capabilities and IT dimensions relate to product development performance? To solve this question, this article embraces the recent focus on a paradoxical approach to management (Lewis, 2000; Gibson and Birkinshaw, 2004) and introduces the concept of ambidexterity in product development. Accordingly, this research focuses on a knowledge paradox where the opposing forces of exploration and exploitation are understood in terms of duality, mutual interdependence, continual change, harmony, and balance. Using this novel view, the study adopts a multi-method approach to understand the mediating role of ambidexterity in the success of product development, while presenting IT -the combination of convergent and divergent dimension of IT- as a driver that can promote the balance of exploration and exploitation activities. This article founds strong evidence that ambidexterity -the simultaneous achievement of exploration and exploitation- mediates the relationship between the IT dimensions encouraging these activities and subsequent performance in product development.

In fact, product development does not seem to involve a trade off between exploration and exploitation (where one occurs at the expense of the other), but a balance of both dimensions. Earlier studies often regarded the trade-offs between these two activities as insurmountable. In the first extreme, the product development comes from the existing knowledge (exploitation). In the second extreme new knowledge is created with loose connections to existing knowledge (exploration). Accordingly, a selection of product development efforts are designated as responsible for exploration, while others are designated as responsible for exploitation. Conversely, this study defends the hypothesis of ambidexterity in product development. In recent research, ambidextrous organizations are capable of simultaneously exploiting existing competences and exploring new opportunities (Raisch, Birkinshaw, Probst and Tushman, 2009).

Previous research has provided mixed messages on the combined use of divergent and convergent IT. Some have suggested that blended different dimensions of IT should prove superior (March, 1991), while others have recommended choosing a single type of IT (Hansen, et al, 1999). The results of this study indicate that achieving ambidexterity in product development through IT is achievable and positively relates to both convergent and divergent IT dimensions. In addition, when this supportive IT creates the capacity for ambidexterity, performance gains are realized. In order to support exploitation in product development, knowledge that may be distributed across different departments or organizational units needs to be retrieved and combined. This may not necessarily imply connecting people but, since knowledge is complex in nature, convergent IT may give support to divergent IT by giving them flexibility. In other words, balanced combinations of convergent and divergent IT support the elimination of structural and temporal barriers so that distributed participants in product develop- 
ment may collaborate and coordinate their work in an interactive way. This combination also supports knowledge location, within and outside the organization, so that available knowledge can be mapped in an internal knowledge base. Therefore, the delicate balance between both the convergent and the divergent dimensions of IT is the one that most affects ambidexterity in product development.

In terms of practice, this article suggests that today organizations and managers confront an increasingly contradictory word (Eisenhardt, 2000), and operation management is not an exception. The traditional unitary approaches that emphasize extreme behaviors are inappropriate (Chae and Bloodgood, 2006). Organizations should recognize and accept ambidexterity in product development practice and put their time and effort to sustaining it rather than avoiding it. Specifically, this study suggests that IT may be an essential element to achieve ambidexterity so that product development managers can design and configure IT to facilitate ambidexterity and nurture both knowledge exploitation and knowledge exploration. Managers must thus overcome the contradictory pressures of exploration and exploitation in product development by managing contradictory dimensions of IT. Divergent IT tends to significantly promote knowledge exploitation by reducing knowledge heterogeneity and consolidating the novelty in dominant design. Convergent IT seems to cultivate knowledge exploration by preserving knowledge variation and innovation, but may be less effective at leveraging knowledge in the short term. However, its effectiveness to support knowledge heterogeneity demands not to reduce opportunities for live interaction or limiting the use divergent IT to avoid knowledge erosion. Hence, combinations of exploration and exploitation occur then in alignment with combinations of convergent and divergent IT to generate a powerful mechanism for competitive advantage. In conclusion, given that product development determines a firm's profits, growth, market share and other key metrics, ambidexterity is likely to be an important and desirable capability that product development managers can develop and which can be shaped, at least partially, through IT.

All results must be viewed in the light of the study's limitations. Each limitation serves as an avenue for future research. First, the focus of this paper is the link between one specific knowledge management enabler, information technology (IT), and ambidex- terity in product development. As such, the study deliberately avoids any attempt to analyze the interrelationship among other knowledge management enablers and ambidexterity. Future research should examine the optimal co-alignment and interrelationship of other knowledge management enablers to deliver superior performance. Second, the scope of this study is limited to firms located in the Madrid area. In addition, sample size is not large. Broadening the study to other geographic areas might lead to conceptual refinement and insight. As a third limitation, this article has tried to define the constructs as precisely as possible by drawing on relevant literature and by closely linking the measures to the theoretical underpinnings through a careful process of item generation and refinement. Evidently, this measurement effort represents an advance for research but, nonetheless, the items are far from being perfect (they measure facts that are neither fully nor easily measurable) or complete (i.e. the use of a single item to measure market performance deserves be enhanced). Fourth, this article opted to study product development function given its prominence in competitiveness and knowledge management literature. Future studies need to examine other functions important to operation management (e.g., supply chain). Fifth, all data were collected from the same respondent using the same perceptual measurement technique. Although the presence of common method is tested and the results show that common method bias should not be a problem, multiple respondents should be considered in future research so as to rule out potential drawbacks. Finally, both the external environment and the organization's internal characteristics naturally interfere with product development efforts thus amplifying or soothing the tendency to explore and/or exploit. Therefore, this work is obviously only a preliminary step to understanding the impact of IT on ambidexterity.

\section{REFERENCES}

Adler, P.S., Goldoftas, B., Levine, D.I. (1999). “Flexibility Versus Efficiency? A Case Study of Model Changeovers in the Toyota Production System", Organization Science, 10 (1), 43-68.

Alavi, M. and Leidner, D.E. (2001). “Review: Knowledge Management and Knowledge Management Systems: Conceptual Foundations and Research Issues", MIS Quarterly, 25 (1), 107136.

Ali, A., Krapfel, R., Jr. ,LaBahn, D.,(1995). “Product Innovativeness and Entry Strategy: Impact on Cycle Time and Breakeven Time", Journal of Product Innovation Management 12 (1), 54-69. 
Anand, B. N. and Khanna, T. 2000. “Do firms learn to create value: The case of alliances", Strategic Management Journal, 21, 295-315.

Anderson, J. C. and Narus, J.A. (1998). “Business Marketing: Understand What Customers Value", Harvard Business Review, (November-December), 53-67.

Andriopoulus, C. and Lewis, M.W. (2009). “Exploration-Exploitation Tensions and Organizational Ambidexterity: Managing Paradoxes of Innovation", Organization Science, 20 (4), 696- 717.

Atuahene-Gima, K. (2005). "Resolving the Capability-Rigidity Paradox in New Product Innovation", Journal of Marketing, 69, 61-83.

Atuahene-Gima, K. and Murray, J.Y. (2007). “Exploratory and Exploitative Learning in Product Development: A Social Capital Perspective on New technology Ventures in China", Journal of International Marketing, 15 (2), 1-29.

Auh, S. and Menguc, S. (2005), "A Test of Strategic Orientation Formation vs. Strategic Orientation Implementation: The Influence of TMT Functional Diversity and Inter-functional Coordination," Journal of Marketing Theory and Practice, 13 (2), 4-19.

Aulakh, P.S. and Gencturk, E.F. (2000), “International Principal-Agent Relationships. Control, Governance and Performance", Industrial Marketing Management, 29: 521-538.

Baron, R.M. and Kenny, D.A. (1986). “The moderator-mediator variable distinction in social psychological research: Conceptual, strategic and statistical considerations", Journal of Personality and Social Psychology, 51, 1173-1182.

Benner, M.J. and Tushman, M.L. (2003). “Exploitation, Exploration and Process Management: The Productivity Dilemma Revisited", Academy of Management Review, 28 (2), 238-256.

Bharadwaj, A. (2000). "A Resource-Based Perspective on Information Technology Capabilities and Firm Performance: An Empirical Investigation", MIS Quarterly, 24 (1), 169-196.

Bierley, P. y Chakrabarti, A. (1996): “Generic Knowledge Strategies in the U.S. Pharmaceutical Industry", Strategic Management Journal, 17 (winter special issue), 123-135.

Chuang, S. (2004). “A Resource-Based Perspective on Knowledge Management Capability and Competitive Advantage: An Empirical Investigation", Expert Systems with Applications, 27, 459-465.

Clark, K. B., and Fujimoto, T. (1991). "Product development performance: Strategy, organization, and management in the world auto industry", Boston, MA: Harvard Business School.

Clark, K.B. and Wheelwright, S.C. (1995): “Leading product development", The Free Press, New York.

Cohen, W. M.; Levinthal, D. A. (1990). “Absorptive-Capacity - A New Perspective on Learning and Innovation", Administrative Science Quarterly, 35 (1), 128-152.

Cooper, R.; Slagmulder, R. (1999): Supply Chain Development for the Lean Enterprise - Interorganizational Cost Management, IMA Foundation for Applied Research, Montvale
Crawford, C.M. (1992). "The hidden cost of accelerated product development", Journal of Product Innovation Management 9 (3), 188-199.

Crossan, M.M., Lane, H.W. and White, R.E. (1999). 'An Organizational Learning Framework: from Intuition to Institution', Academy of Management Review, 24 (3), 522-537.

Danneels, E. (2002). "The Dynamics of Product Innovation and Firm Competences", Strategic Management Journal, 23 (12), 1095-1121.

Davenport, T.H. and Prusak, L. (1998). Working Knowledge. How Organizations Manage What They Know, Harvard Business School Press. Boston, Massachusetts. 1998.

Duncan, R.B. (1976). “The ambidextrous Organization: Designing Dual Structures for Innovation". In Kilmann, R.H., Pondy, L.R. and Slevin, D.P., The Management of organization Design, Volume I Strategies and Implementation, New York: Elsevier North-Holland.

Eisenhardt, K. M. and Behnam N. T., (1995): “Accelerating Adaptive Processes: Product Innovation in the Global Computer Industry", Administrative Science Quarterly, 40, 84-110.

Fedor, D.B., Ghos, S., Caldwell, S.D., Maurer, T.J. and Singhal, V.R. (2003). "The Effects of Knowledge Management on Team Members' Ratings of Project Success and Impact", Decision Sciences, 34 (3), 513-539.

Fliess, S. and Becker, U. (2006). "Supplier Integration: Controlling of Codevelopment Processes", Industrial Marketing Management 35 (1), 28-44.

Floyd, S.W. and Lane, P.J. (2000). "Strategizing Throughout the Organization: Management Role Conflicting in Strategic Renewal", Academy of Management Review, 25, 154-177.

Ghemawat, P. and Costa, J.E. (1993). “The Organizational Tension Between Static and DynamicEfficiency", Strategic Management Journal, 14, 59-73.

Gibson, C. B. and Birkinshaw, J. (2004). “The Antecedents, Consequences, and Mediating Role of Organizational Ambidexterity", Academy of Management Journal, 47 (2), 209-226.

Gold, A.H., Malhotra, A. and Segars, A.H. (2001). "Knowledge Management: An Organizational Capabilities Perspective", Journal of Management Information Systems, 18 (1), 185-214.

Grant, R. (1996). "Toward a Knowledge-Based Theory of the Firm", Strategic Management Journal, 17 (Winter special Issue), 199-122.

Handfield, R. and Nichols, E.L. (2002). Supply Chain Redesing: Transforming Supply Chains into Integrated Vertical Value System, Financial Times Prentice Hall.

He, Z. and Wong, P. (2004). "Exploration vs. Exploitation: An Empirical Test of the Ambidexterity Hypothesis". Organization Science, 15 (4), 481- 494.

Hong, P (2000). “Knowledge Integration in Integrated Product Development", Doctoral Thesis. University of Toledo, USA

Hong, P., Vonderembse, M., Doll, W. J, and Nahm, A. (2005).“Role Changes of Design Engineers in Integrated Product Development", Journal of Operations Management, 24(1), 63-79. 
Hult, G. T., Ketchen, D.J., Cavusgil, S.T. and Calantone, R.J. (2006). "Knowledge as a Strategic Resource in Supply Chain", Journal of Operations Management, 24, 458-475.

Jansen, J.J.P., Van den Bosch, F.A.J. and Volverda, H.W. (2005). “Explorative Innovation and Exploitative Innovation, and Ambidexterity: The Impact of Environmental and Organizational Antecedents", Schmalenbach Business Review, 57, 351-363.

Kane, G.C. and Alavi, M. (2007): Information technology and organizational learning: An investigation of exploration and exploration processes", Organization Science, 18 (5), 796-812.

Katila, R. and Ahuja, G. (2002). "Something Old, Something New: A Longitudinal Study of search Behaviour and New Product Introduction", Academy of Management Journal, 45 (6), 1183-1194

Kauppila, O. (2007). “Towards a network Model of Ambidexterity", Unpublished Working Paper, Helsinki School of Economics.

Kenny, D.A., Kashy, D.A. and Bolger, N. (1998). “Data analysis in social Psicology". In D. Gilbert, S. Fiske\&G. Lindzey (Eds.), The Handbook of Social Psychology, 1 ( $4^{\text {th }}$ ed.), Boston: McGrawHill , 233-265.

Koufteros, X. A., Cheng, T.C. E. and Kee-Hung, L. (2007). “ Black -box and Gray-box Supplier Integration in Product Developmet: Antecedents, Consequences and the Moderating Role of Firm Size", Journal of Operations Management, 25, 847-870.

Kyriakopoulous, K. and Moorman, C. (2004). "Tradeoffs in Market Exploitation and Exploration Strategies: The Overlooked Role of Market orientation", International Journal of Research in Marketing, 21, 219-240.

Lawson, B. and Samson, D. (2001). "Developing Innovation Capability in Organisations: A Dynamic Capabilities Approach", International Journal of Innovation Management, 5 (3), 377-400.

Lee, H. and Choi, B. (2003). “Knowledge Management Enablers, Processes, and Organizational Performance: An Integrative View and Empirical Examination", Journal of Management Information Systems, 20 (1), 179-228.

Leonard Barton, D. (1992). "Core Capabilities and Core Rigidities: A Paradox in Managing New Product Development", Strategic Management Journal, 13 (8), 111-125.

Levinthal, D.A. and March, J.G. (1993). "The Myopia of Learning". Strategic Management Journal, 14, 95-112.

Lewis, M.W. (2000). “Exploring Paradox: Toward a More Comprehensive Guide", Academy Management Review, 25, 760-777

Lubatkin, M.H., Simsek, Z., Ling, Y. and Veiga, J.F. (2006). “Ambidexterity and Performance in Small to Medium-Size Firms: The Pivotal Role of Top Management team Behavioral Integration", Journal of Management, 32 (5), 646-672.

MacKinnon, D.P. and Dwyer, J.H. (1993). “Estimating mediated effects in prevention studies", Evaluation Review, 17 (2), 144-158.

Madhavan, R. and Grover, R. (1998): “From Embedded Knowledge to Embodied Knowledge: New Product Development as Knowledge Management", Journal of Marketing, 62, October: 1-12.
Mallic, D.M. and Schroeder, R.G. (2005). “An Integrated Framework for Measuring Product Development Performance in High Technology Industries", Production and Operations Management; 4, (2), 142-158.

March, J.G. (1991). “Exploration and Exploitation in Organizational Learning", Organization Science, 2 (1), February, 71-87.

Melville, N., Kraemer, K. and Gurbaxini, V. (2004). “Review: Information technology and Organizational Performance: an Integrative Model of IT Business Value", MIS Quarterly, 28 (2), 283-322.

Menguc, B. and Auh, S. (2008), “The Asymetric Moderating Role of Market Orientation on the Ambidexterity-Firm Performace Relationship for Prospectors and Defenders", Industrial Marketing Management, 37, 455-470.

Mohrman, S.A. and Finegold, D. and Mohrman, A.M (2003): “An Empirical Model of the Organization Knowledge System in New Product Development Firms", Journal of Engineering and Technology Management, 20, 7-38.

Neely, A. and Adams, C. (2001): “Perspectives on Performance: The Performance Prism". http: //www.som.cranfield.ac.uk/ som/cbp/prismarticle.pdf.

Nonaka, I. and Takeuchi, H. (1995). The Knowledge Creating Company, Oxford University Press, New York.

Nonaka, I., Toyama, R. and Nagata, A. 2000. “A Firm as a Knowledge-Creating Entity: A New Perspective on the Theory of the Firm", Industrial and Corporate Change, 9 (1), 1-20.

Podsakoff P.M, MacKenzie B., Lee J-Y and Podsakoff N.P. (2003). "Common Method Biases in Behavioural Research: A Critical Review of the Literature and Recommended Remedies", Journal of Applied Psychology, 88 (5), 879-903.

Raisch, S and Birkinshaw, J. (2008). "Organizational Ambidexterity: Antecedents, Outcomes and Moderators", Journal of Management, 34 (3), 375-409.

Raisch, S; Birkinshaw, J.; Probst, G. and Tushman, M (2009): “Organizational Ambidexterity: Balancing Exploitation and Exploration for Sustained Performance", Organization Science, 20(4), 685-695.

Revilla, E., Rodriguez, B. and Prieto, I. 2009. Information Technology as a Knowledge

Management Enabler in Product Development: Empirical Evidence", European

Journal of Innovation Management, 12 (3): pp. 346-363

Robey, D., Boudreau, M. and Rose, G.M. (2000). "Information Technology and Organizational Learning: a Review and Assessment of Research", Accounting Management and Information Technologies, 10, 125-155.

Rosenau, M. (1989): “Schedule Emphasis of New Product Development Personnel", Journal of Product Innovation Management, 6 (4), 282-288

Sambamurthy, V. and Subramani, M. (2005). “Special Issue on Information Technologies and Knowledge Management", MIS Quart. 29 (1), 1-7. 
Sanders, N. R. (2008). "Pattern of Information Technology Use:The Impact on Buyer-Supplier Coordination and Performance", Journal of Operations Management, 26, 349-367.

Santhanam, R. and Hartono, E. (2003) "Issues in Linking Information Technology Capability to Firm Performance," MIS Quarterly, 27 (1),125-153.

Schiling, M.A. and Hill, C.W.L. (1998): “Managing the New Product Development Process: Strategic Imperatives", Academy of Management Executive, 12 (3), 67-81.

Scott, J.E. (2000). “Facilitating Interorganizational Learning with Information Technology", Journal of Management Information Systems, 17 (2).

Sharki, R. (2003): "Knowledge creation and its place in the development of sustainable competitive advantage", Journal of Knowledge Management, 7, 20-31.

Sher, P.J. and Lee, V.C. (2004). "Information Technology as a Facilitator for Enhancing Dynamic Capabilities through Knowledge Management", Information \& Management 41, 933-945.

Sheremata, W.A. (2000). "Centrifugal and Centripetal Forces in Product Development", Academy of Management Review, 25: 389-408.

Slater, S.F. and Narver, J.C. (1995). “Market Orientation and the Learning Organization", Journal of Marketing, 59 (3), 63-74.

Smith, W.K. and Tushman, M.L. (2005). "Managing Strategic Contradictions: A Top Management Model for Managing In- novation Streams", Organization Science, 16, 522-536.

Sobel, M.E.(1982). “Asymptotic Confidence Intervals for Indirect Effects in Structural Equation Model". In S. Leinhart (Ed.), Sociological Methodology, San Francisco: Jossey-Bass, 219-312.

Tanriverdi, H. (2005). “Information Technology Relatedness, Knowledge Management Capability, and Performance of Multibusiness Firms", MIS Quarterly, 29 (2), 311-334.

Tersine, R.J. and Hummingbird, E.A. (1995). “Lead-time Reduction the Search for Competitive Advantage, International Journal of Operations and Production Management, 12 (2), 8-18.

Tippins, M. J. and Sohi, R.S (2003). "IT Competency and Firm Performance: Is Organizational Learning a Missing Link?", Strategic Management Journal, 24 (8), 745-761.

Tushman, M.L. and O’Reilly, C.A. (1996). “Ambidextrous Organizations: Managing Evolutionary and Revolutionary Change", California Management Review, 38 (4), 8-30.

Van den Brink, P. (2003). “Social, Organizational and Technological Conditions that Enable Knowledge Sharing", Doctoral thesis, Technische Universiteit Delft, Amsterdam.

Zirger, B. J. and Maidique, M. (1990). "A Model of New Product Development: An Empirical Test", Management Science, 36, 867-883.

Zollo, M. and Winter, S.G. (2002). “Deliberate Learning and the Evolution of Dynamic Capabilities", Organization Science, 13 (3), 339-351.

\section{AUTHOR'S BIOGRAPHY}

Isabel M. Prieto is an associate professor of Business Administration at the Department of Business Management and Market Research at the University of Valladolid, Spain, since 1996. She received her Ph.D. from the University of Valladolid with a concentration in knowledge management and learning in organizations in 2003. In 2004/5 she was post-doctoral visiting scholar in the Lancaster University Management School, UK. Her current research is on knowledge processes and organizational learning in relation to human resources management.

Elena Revilla is professor of Operations Management at IE Business School, Spain. Elena holds a doctoral degree in Economics \& Business Administration from the Universidad de Valladolid (Spain). She also holds an MA in Science and Technology from Universidad Carlos III, Madrid. She was a post-doctoral fellow at University of North Carolina, Chapel Hill and visiting researcher in MIT. She received the 1996 award for the best doctoral dissertation granted by the Club Gestión de Calidad. She has published in journals including Journal of Operations Management, Decision Sciences, Journal of the Operation Research Society, International Journal of Production Economics, International Journal of Production Operation Management, International Journal of Technology Management, Scandinavia Management Journal, Management Learning, European Journal of Innovation Management, etc. Her research interest is organizational behaviour in operational and supply chain management context.

Beatriz Rodriguez is an associate professor of Statistics and Econometrics at the Applied Economic Department at the University of Valladolid, Spain. She holds a Doctorate in Economics from University of Valladolid and received the award from the University of Valladolid for the best doctoral thesis. She was Post-doctoral Fellow in Department of Economics at the University of California in San Diego. Her research is focused in applied econometrics and multivariate analysis with special attention to labour market performance and macroeconomic forecasting. She is also an expert in evaluating the European Structural and Cohesion Fund programmes. 